\title{
Eğitim Fakültesi Öğrencilerinin Öğretim Elemanlarından Beklentileri ve Beklentilerinin Karşılanma Düzeyine İliş̧kin Görüşleri
}

\section{School of Education Students' Expectations from Their Lecturers and Their Views on Whether These Are Fulfilled}

\author{
Özlem ÖZÇAKIR SÜMEN* \\ Ondokuz Mayıs Üniversitesi \\ Alper KESTEN ${ }^{* *}$ \\ Ondokuz Mayıs Üniversitesi
}

\begin{abstract}
Özet
Toplumların yeni nesillerini yetiştirecek öğretmenleri eğitmeleri açısından üniversite öğretim elemanlarının önemi büyüktür. Öğretmenlerimizin ideal özelliklere sahip olabilmesi için öncelikle onları yetiştiren öğretim elemanlarımızın ideal özelliklere sahip olması gerekmektedir. Bu çalışma, üniversite öğrencilerinin üniversiteye başlamadan önce öğretim elemanlarından beklentilerini ve üniversiteye başladıktan sonra öğretim elemanlarının bu beklentileri ne derece karşıladıklarını belirlemek amacıyla yapılmıştır. Araştırmada nitel araştırma yöntemlerinden durum çalışması kullanıımıştır. Veriler Ondokuz Mayıs Üniversitesi İlköğretim Bölümü farklı anabilim dallarında okuyan 20 öğrenci ile yapılan yarı yapılandırılmış görüşmelerle elde edilmiştir. Araştırma sonucunda; öğrencilerin üniversiteye başlarken ve bitirdikten sonraki düşünceleri arasında önemli değişiklikler olduğu belirlenmiştir. Araştırmanın sonuçları, öğrencilerin üniversite ortamını çok soğuk ve resmi beklerken oldukça samimi ve içten bir eğitim ortamı bulduklarını, derslerde öğrenci merkezli yöntemlerin işlenmesini beklerken geleneksel yöntemlerin ağırlıklı olarak uygulandığı ortaya koymuştur. Ayrıca öğrenciler, öğretim elemanlarının kendilerine yeterince değer vermediklerini düşündüklerini ve bilgi düzeylerinin üst seviyede olmasına rağmen bildiklerini öğrencilere aktarmada sıkıntı yaşadıklarını ifade etmişlerdir.
\end{abstract}

Anahtar Kelimeler: Öğretim elemanları, Eğitim fakültesi, Öğrencilerin öğretim elemanlarından beklentileri

\begin{abstract}
University lecturers play a pivotal role in that they train the teachers who in turn educate the young generations of a society. This study seeks to unveil what university students expect from their lecturers before they start their studies and how much these expectations are met afterwards. The research makes use of case study, one of the qualitative research methods, with data obtained from the semi-structured interviews conducted with 20 students. The findings suggest significant changes in students' opinions before and after the start of their studies: the students expecting a cold and bureaucratic environment at university have found a friendly and cosy setting while those expecting student-centred teaching methods have witnessed more traditional methods instead. The students have also expressed their feeling
\end{abstract}

\footnotetext{
*Ondokuz Mayıs Üniversitesi, Eğitim Fakültesi İlköğretim Bölümü, Samsun,ozlem.ozcakir@omu.edu.tr

** Ondokuz Mayıs Üniversitesi, Eğitim Fakültesi İIköğretim Bölümü, Samsun, akesten@omu.edu.tr
} 
that the lecturers do not quite appreciate them and that, even though they are highly knowledgeable, they have difficulty conveying this knowledge to the students. their lecturers

Key Words: University lecturers, School of education, Students' expectations from

\section{Giriş}

Üniversite eğitimi, bilim ve teknolojinin baş döndürücü bir hızla geliştiği dünyamızda çok önemli bir yere sahiptir. Bu önemin farkında olan aileler üniversiteye çocuklarını yerleştirmek ve iyi bir eğitim almalarını sağlamak için olağanüstü çabalar harcamaktadır. Bu amaçla yapılan üniversiteye giriş sınavları her yıl binlerce öğrencinin girdiği ve çok azının kazanabildiği sınavlardır. Bu sınavlardan yüksek puanlar alan, dereceye giren öğrenciler en iyi üniversiteye gidebilmek, kaliteli bir eğitim almak hayaliyle tercih yapmaktadır. Zorlukla girilen üniversitelerde öğrencilerin alacakları eğitim konusunda beklentileri de üst düzeyde olmaktadır. Ancak bu beklentilerle üniversiteye başlayan öğrencilerin duygu ve düşünceleri zaman içinde nasıl şekillendiği, üniversitelerin öğrencilerin beklentilerini ne ölçüde karşıladığıysa tam olarak bilinmemektedir.

Alan ve meslek bilgisi, değer yargıları, dünya görüşleriyle öğrencilerin tutum ve davranışlarını etkileyen öğretmen, devletin eğitim politikasını eğitim ortamında uygulamaya koyan, uygulama sonuçları ile bu politikayı etkileyen, eğitimde uzmanlık çalışmaları ve araştırmalardan yararlanan kişidir (Varış, 1994). Davranış değiştirme mühendislerinin yani eğitimcilerin amacl; eğitim sürecinde geçerli öğrenmeleri sağlamak, istenmedik hatalı ürünleri en aza indirmek hatta yok etmektir (Senemoğlu, 2011). Topluma öğretmen yetiştiren kurumlar olan üniversitelerin bu konuda önemi büyüktür. Öğretim elemanlarının hem mesleki özellikleri hem de kişilik özellikleri; bizim çocuklarımızı emanet ettiğimiz, geleceğimizi yetiştirecek öğretmenleri şekillendirmeleri bakımından büyük önem arz etmektedir.

Üniversite öğrencilerinin öğretim elemanlarından beklentilerini ve üniversite ortamında bu beklentilerinin karşılanma düzeyini belirlemeye yönelik birçok çalışma yapılmıştır. Bu konuda yurt dışında yapılan çalışmalara baktığımızda; Gregory (2012), öğrencilerin profesörleri değerlendirdiği popüler bir site olan 'Rate My Professor' web sitesinde beğenilen profesörlerin yardımsever ve ilgili, sınıflarının eğitici, özenli ve adil olduğunu; kaliteli öğrenme ve öğretmenin de böyle oluştuğu bulmuştur. Öğrenci gözüyle en iyi profesörler iyi iletişim kuran, yardım eden, iyi öğreten, farklı yöntemler kullanan, eğlenceli ders anlatan, motive eden, öğrenciyi derse katan ve bilgi sahibi; zayıf profesörler ise iletişimsiz, öğrenmenin olmadığı, öğretim ve zaman yönetiminde zayıf, öğrenciyle ilgilenmeyen, saygı duymayan, profesyonel davranmayan, sıkıcı, farklı yöntemler kullanmayan kişiler olarak belirlenmiştir (Slate ve diğ. 2009). Çin' de yapılan bir çalışmada favori öğretmenler müfredat ve eğitimle ilgili bilgi sahibi, öğrencinin öğrenmesini sağlamak için ders kitabı ve alıştırmalar arasında bağlantılar kuran, öğrencilerle ilgilenirken daha öğrenci merkezli yaklaşımlar kullanan kişiler olarak belirlenmiştir. En az favori öğretmenler ise, öğretmekten çok araştırmaya odaklananlar, öğretme yeteneğini geliştirmenin önemini bilmeyenler ve iletişim kurulması zor kişiler olarak bulunmuştur (Tam ve diğ. 2009). Üniversite öğrencileri etkili öğretmen özelliklerini çeşitli öğretme stratejileri kullanma, alanında uzman, öğrencilere saygı ve ilgi gösterme; zayıf öğretmen özelliklerini ise iyi öğretememe, öğrenmenin ortaya çıkmaması, kötü sınıf yönetimi, 
kötü davranma, öğrencilerle iletişim kurmama olarak belirtmişlerdir. (Wang ve diğerleri, 2007).

Öğrencilerin öğretim elemanlarından beklentileri ve öğretim elemanlarının gerçekte sahip oldukları özellikleri belirlemeye yönelik yurtiçinde de birçok çalışma yapıldığı görülmektedir. Üniversite öğrencilerine göre, öğretim elemanlarının yarısından çoğu "öğretim strateji-yöntem ve tekniklerini kullanma", "iletişim" ve "ölçme-değerlendirme" becerileri açısından yeterli düzeyde değildir (Arslantaş, 2011). İlköğretim matematik öğretmen adaylarının öğretim elemanlarında benimsediği kişisel özellikler sevecen, prensip sahibi ve prensiplerinden ödün vermeme, sıcakkanlı, öğrenciyi sevme, kendini üstün görmeme, eleştiriye açık; benimsenmeyen özellikler ise çok sert, otoriter, asabi, kendini üstün görme, kendi doğrularıyla insanları yönlendirme, eleştiriye kapalı ve öğrencileri sevmeme olarak belirlenmiştir (Özdemir ve Üzel, 2010). Öğretmen adaylarına göre, olumlu öğretim elemanı davranışları derse hazırlıklı ve zamanında gelme, öğrenci ile iyi bir iletişim ve paylaşma, öğrenciye değer verme, saygı gösterme, alanı ve formasyonu ile ilgili yeterlik, derslerinde daha esnek kurallara başvurma şeklinde sıralanırken; öğretim elemanlarının olumsuz davranışları ise iletişim kopukluğu ya da yetersizliği, alanda ve formasyonda zayıflık, katı tutumlar, öğrenciye karşı saygısız ve küçümseyici tavırlar şeklindeki temalarda toplanmıştır (Kumral, 2009). Öğretmen yetiştiren kurumlarda öğretim elemanlarının etkili öğretmenlik özelliklerinin belirlendiği başka bir çalışmada öğrenciler, etkili öğretmen özelliklerinin büyük bir çoğunluğunun öğretim elemanlarının "bir kısmı" tarafından yapıldığı veya öğretim elemanlarının "bir kısmı"nın bu davranışlarda yeterli olduğunu belirlenmiştir (Şen ve Erişen, 2002). Ergün ve diğerlerinin (1999) yaptığı araştırmaya göre, öğrencilerin öğretim elemanlarından istedikleri davranışlar şunlardır: İdeolojik propaganda yapmama, öğrenci kişiliğine değer verme, samimi davranma, kibirli davranmama, iletişim kurma, rehberlik etme, dersini öğrenciye iyi anlatabilme, dersi çekici hale getirme, örneklendirme. Saylan ve Uyangör (1998) araştırmalarında, eğitim fakültesi öğrencilerinin alan bilgisi ve genel kültür öğretim elemanlarını orta derecede değerlendirirken, öğretmenlik meslek bilgisi öğretim elemanlarını iyi derecede değerlendirdiğini bulmuşlardır. Başka bir çalışmada ise, ideal bir öğretim elemanında bulunması gereken nitelikler konusunda öğrenciler ve öğretim elemanları aynı noktada birleşirken, gerçekte sahip oldukları özellikler açısından öğrenciler öğretim elemanlarına göre daha düşük oranlar belirtmişlerdir (Akgöl, 1994). Beyhan (1994), öğrencilerin, öğretim elemanlarına oranla kendi kurumlarındaki öğretim elemanlarını daha olumsuz değerlendirdiğini bildirmiştir. Öğretim elemanlarının yeterliliklerinin belirlenmeye çalışıldığı bir araştırmada öğretim elemanları birçok alanda kendilerini yeterli görürken öğrenciler öğretim elemanlarını orta düzeyde yeterli veya yetersiz bulmaktadır (Köseoğlu, 1994).

$\mathrm{Bu}$ çalışmanın üniversite öğrencilerinin bakış açısıyla öğretim elemanlarının değerlendirildiği nitel çalışmalara katkı sağlayacağı düşünülmektedir çünkü bu konuda yapılan nitel çalışmaların azlığı dikkat çekmektedir. Çalışmanın amacı, eğitim fakültesi ilköğretim bölümü öğrencilerinin öğretim elemanlarından beklentilerini ve bu beklentilerin karşılanma düzeyini ortaya koymaktır. Bu amaçla şu sorulara cevap aranmıştır;

1. Eğitim fakültesi ilköğretim bölümü birinci ve dördüncü sınıfta öğrenim gören üniversite öğrencileri üniversiteye başlamadan önce öğretim elemanlarının hangi özelliklere sahip olduklarını düşünüyorlardı? 
2. Öğretim elemanları öğrencilerin beklentilerini ne ölçüde karşılamışlardır?

\section{Yöntem}

Bu çalışmada nitel araştırma yöntemlerinden durum çalışması kullanılmıştır. Nitel durum çalışmasının en temel özelliği bir durumun derinliğine araştırılmasıdır. Bir duruma ilişkin etkenler bütüncül bir yaklaşımla araştırılır ve ilgili durumu nasıl etkiledikleri ve ilgili durumdan nasıl etkilendikleri üzerine odaklanılır (Yıldıım ve Şimşek, 2011). Veriler öğrencilerle yapılan yarı yapılandırılmış görüşmelerle toplanmıştır.

\section{Çalışma Grubu}

Bu çalışma, 2011-2012 eğitim öğretim yılında Ondokuz Mayıs Üniversitesi Eğitim Fakültesinde yapılmıştır. Araştırmanın örneklemi aykırı örneklem yöntemine göre seçilen İlköğretim bölümü farklı anabilim dallarında öğrenim gören 1 . ve 4 . sınıf öğretmen adaylarından oluşmaktadır. Üniversiteye başlayan öğrencilerin hangi beklentilerle geldiklerini, bitirenlerin ne düşünerek bitirdiklerini belirleyebilmek için örneklem grubu geniş tutulmuş ve ilköğretim bölümündeki her anabilim dalından öğrenciler seçilmiştir. Buna göre görüşmeler sınıf öğretmenliği birinci sınıftan iki öğrenci, dördüncü sınıftan iki öğrenci; matematik öğretmenliği birinci sınıftan iki öğrenci, dördüncü sınıftan iki öğrenci; fen bilgisi öğretmenliği birinci sınıftan iki öğrenci, dördüncü sınıftan iki öğrenci; sosyal bilgiler öğretmenliği birinci sınıftan iki öğrenci, dördüncü sınıftan iki öğrenci ve okul öncesi öğretmenliği birinci sınıftan iki öğrenci, dördüncü sınıftan iki öğrenci olmak üzere toplam 20 öğrenci ile gerçekleştirilmiştir. Nitel araştırmalarda amaç, nicel araştırmalardan farklı olarak daha küçük gruplarla daha ayrıntılı ve derinlemesine veri elde etmektir (Yıldırım ve Şimşek, 2011). Bu nedenle örneklem sayısı 20 öğrenci ile sınırlandırılmıştır.

\section{Veri Toplama Aracı}

Bu çalışmada; ilköğretim bölümü öğretmen adaylarının, öğretim elemanlarının özellikleri hakkındaki görüşlerini almak amacıyla, Milli Eğitim Bakanlığı Öğretmen Yetiştirme ve Eğitimi Genel Müdürlüğü tarafından 2006 yılında Temel Eğitime Destek Projesi kapsamında yayınlanan "Öğretmenlik Mesleği Genel Yeterlikleri" göz önüne alınarak araştırmacı tarafından görüşme soruları hazırlanmıştır. Öğretmenlerin ve öğretmen adaylarının mesleki yeterliliklerinin belirlenmeye çalışıldığı birçok çalışmada MEB tarafından yayınlanan Öğretmenlik Mesleği Genel Yeterliklerinden faydalanıldığı görülmektedir (Numanoğlu ve Bayır, 2009; Gelen ve Özer, 2008; Akpınar ve diğ., 2004). Görüşme soruları öğretim elemanlarının kişisel ve mesleki özelliklerini belirlemeye yönelik hazırlanan toplam altı soru ve sonda sorulardan oluşmuştur. Burada görüşme formunda yer alan sorulardan iki tanesine örnek olarak yer verilmiştir:

1. A. Üniversiteye başlamadan önce öğretim elemanlarının nasıl bir "öğretme ve öğrenme süreci" izlediklerini düşünüyordun?

ALTERNATIF: Üniversitedeki eğitim ortamı, derslerin işlenişiyle ilgili olarak düşüncelerin nelerdi?

Sonda: Dersin plânlaması, kullanılan materyaller, öğrenme ortamlarının düzenlenişi, ders dışı etkinlikler, sınıf yönetimi, gibi. 
B. Üniversiteye başladıktan sonra öğretim elemanlarının derslerdeki "öğretme ve öğrenme sürecini ve dersleri işleyişini" nasıl buldun?

2. A. Üniversiteye başlamadan önce öğretim elemanlarını "ölçme ve değerlendirme" yaklaşımları açısından nasıl hayal ediyordun?

ALTERNATİ: Öğretim elemanlarının öğrencilerin öğrenmelerini tespit etmek için nasıl bir ölçme ve değerlendirme sistemi uyguladıklarını düşünürdün?

Sonda: Ölçme ve değerlendirme yöntem ve teknikleri, değişik ölçme tekniklerini kullanarak öğrencinin öğrenmelerini ölçme, geri bildirim sağlama, sonuçlara göre öğretme-öğrenme sürecini gözden geçirme, gibi.

B. Üniversiteye başladıktan sonra öğretim elemanlarının "ölçme ve değerlendirmede izledikleri yöntemler" açısından nasıl buldun?

Sorular uzman görüşüne sunularak gerekli düzeltmeler yapılmıştır. Soruların anlaşılabilirliğini sağlamak amacıyla uygulama öncesi pilot görüşme yapılmış ve soruların anlaşılmayan kısımları düzeltilerek görüşme sorularına son şekli verilmiştir. Öğretmen adaylarından öğretim elemanlarıyla ilgili olarak bu soruları ve sonda soruları yanıtlamaları istenmiştir. Görüşmeler araştırmacının ofisinde gerçekleştirilmiş ve ortamın sessiz olmasına özellikle dikkat edilmiştir. Her öğrenciyle ayrı ayrı gerçekleştirilen görüşmeler ortalama 15-20 dakika sürmüştür. Görüşmeler ses kayit cihazı kullanılarak kaydedilmiş, daha sonra veriler bilgisayarda transkript edilmiştir.

\section{Veri Analizi}

Görüşmelerden elde edilen verilerin araştırmacı tarafından içerik analizi yapılmıştır. İçerik analizinde temel amaç toplanan verileri açıklayabilecek kavramlara ve ilişkilere ulaşmaktır. İçerik analizinde, birbirine benzeyen veriler belirli kavramlar ve temalar çerçevesinde bir araya getirilir ve bunlar okuyucunun anlayabileceği bir biçimde düzenlenerek yorumlanır (Yıldıım ve Şimşek, 2011). Veriler araştırmacı tarafından kodlanmış ve yapılan kodlamalar uzman görüşüne sunulmuştur. Oluşturulan kodların frekans değerleri hesaplanarak tablolaştırılmıştır. Ayrıca öğrenci görüşlerinden doğrudan alıntılar yapılarak okuyucunun konu hakkında derinlemesine bilgi sahibi olmasına olanak tanınmıştır. Veriler analiz edilirken öğrencilerin isimleri alanlarına göre adlandırımıştır. Örneğin ilköğretim matematik öğrencileri 1 . sınıf M1a, M1b; 4. sınıf M4a, M4b; sınıf öğretmenliği öğrencileri 1. sınıf S1a, S1b; 4. sınıf S4a, S4b; fen bilgisi öğrencileri 1. sınıf F1a, F1b; 4. sınıf F4a, F4b; okul öncesi 1. sınıf O1a, O1b; 4. sınıf O4a, O4b ve sosyal bilgiler 1. sınıf SB1a, SB1b; 4. sınıf SB4a ve SB4b şeklinde kodlanmıştır.

\section{Bulgular}

Bu bölümde öğretmen adaylarıyla yapılan görüşmeler araştırmanın amaçları doğrultusunda analiz edilerek sunulmuştur. İçerik analizi yapılırken öğretim elemanlarının özellikleri kişisel ve mesleki özellikler olmak üzere iki başılık altında toplanmıştır.

\section{Öğretim Elemanlarının "Kişisel Özellikleri" ile İlgili Üniversite Öğrencilerinin Düşünceleri}


Tablo 1. Öğretim elemanlarının "kişilik özellikleri" ile ilgili öğrenci düşünceleri

\begin{tabular}{|c|c|c|c|c|c|c|c|c|}
\hline & & & 岌 & $\begin{array}{l}\frac{\omega}{\mathbf{E}} \\
\bar{n} \\
\dot{v}\end{array}$ & $\begin{array}{l}\Xi \\
\varepsilon \\
\frac{E}{0} \\
\text { 음 }\end{array}$ & 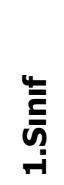 & $\begin{array}{l}\dot{U} \\
\overline{\mathbf{E}} \\
\dot{+}\end{array}$ & $\begin{array}{l}\Xi \\
\varepsilon \\
\frac{E}{0} \\
0\end{array}$ \\
\hline & & & \multicolumn{3}{|c|}{$\begin{array}{l}\text { Üniversiteye } \\
\text { başlamadan } \\
\text { önce }\end{array}$} & \multicolumn{2}{|c|}{$\begin{array}{l}\text { Üniversiteye } \\
\text { başladıktan } \\
\text { sonra }\end{array}$} & \\
\hline \multirow{8}{*}{$\begin{array}{l}\text { Öğrenci } \\
\text { ilişkileri }\end{array}$} & Samimi & & 2 & 1 & 3 & 9 & 8 & 17 \\
\hline & Resmi & & 8 & 9 & 17 & 1 & 2 & 3 \\
\hline & \multirow{2}{*}{$\begin{array}{c}\text { Öğrenciye değer } \\
\text { verme }\end{array}$} & Evet & 2 & 4 & 6 & 3 & 3 & 6 \\
\hline & & Hayır & 8 & 6 & 14 & 6 & 7 & 13 \\
\hline & \multirow[t]{2}{*}{ Rehberlik etme } & Evet & 3 & 4 & 7 & 5 & 4 & 9 \\
\hline & & Hayır & 3 & 2 & 5 & 4 & 4 & 8 \\
\hline & \multirow{2}{*}{$\begin{array}{l}\text { Eleştiriye açık } \\
\text { olma }\end{array}$} & Açık & 5 & 8 & 13 & 2 & 1 & 3 \\
\hline & & Kapalı & 3 & 1 & 4 & 5 & 8 & 13 \\
\hline \multirow{4}{*}{$\begin{array}{l}\text { Toplum } \\
\text { ilişkileri }\end{array}$} & Samimi & & 2 & 7 & 9 & 6 & 3 & 9 \\
\hline & Resmi & & 7 & 3 & 10 & 2 & 6 & 8 \\
\hline & \multirow{2}{*}{$\begin{array}{l}\text { Liderlerle/ } \\
\text { kurumlarla işbirliği }\end{array}$} & Var & 3 & 3 & 6 & 2 & & 2 \\
\hline & & Yok & & & & 3 & 3 & 6 \\
\hline
\end{tabular}

\section{Öğrenci ilişkileri}

Çalışma sonuçlarına öğretim elemanı-öğrenci ilişkileri boyutunda bakıldığında öğrencilerin üniversiteye ilk geldiklerinde büyük çoğunlukla $(f=17)$ daha resmi ve soğuk bir ortam beklediklerini ifade ettikleri görülmüştür. Ancak ilginç bir şekilde öğrencilerin neredeyse tamamı $(\mathrm{f}=17)$ bu konuda yanıldıklarını samimi bir şekilde itiraf etmiş ve düşündüklerinin aksine öğretim üyelerinin kendileriyle olan ilişkilerinde samimi ve içten ilişkiler içinde olduklarını ifade etmişlerdir.

"Hoca dersini anlatır gider, öğrenciyle pek muhatap olmaz, diye bekliyordum. Ortamı daha resmi bekliyordum. Ama hiç öyle değil, hocalar daha samimi. Odasına girebiliyoruz." (SB1b)

"Üniversiteye gelmeden önce hocalarla ilgili çok hikayeler duydum. Daha soğuk, resmi, otoriter hocalar bekliyordum. Hocalara soru bile sorabileceğimi sanmıyordum. Geldikten sonra gelmeden önceki düşüncelerimin tam tersi çıktı, doğrusunu söylemek gerekirse. Hocalarla ilişkilerim daha iyi, daha samimi oldu. Ortamın sıcak ve samimi olduğunu düşünüyorum." (SB4b)

$\mathrm{Bu}$ noktada asıl ilginç bulgu ise ilişkilerdeki bu samimi ve içten havanın öğrenciye değer verme noktasına yansımamış olmamasıdır. Öğrencilerin önemli bir kısmı ( $f=13)$ üniversite ortamında öğretim elemanlarının öğrenciye değer vermeyecekleri ön yargısıyla üniversiteye girdiklerini ifade etmişlerdir. Öğrenciler geçen süre zarfında da bu görüşlerini destekleyici tavırlarla karşılaştıklarını ve öğretim üyelerinden hakkettikleri değeri görmediklerini ifade etmişler hatta bu 
görüşte olmadan üniversiteye gelen bir kısım öğrencilerin de bu konuda olumsuz yönde fikir değişikliğine gittikleri görülmüştür $(f=14)$.

"[Öğretim elemanlarının] Öğrenciye değer vereceklerini düşünmüyordum. Gerçekten çoğu öğrenciye değer vermiyor. Birey olarak görmüyor." (S4b)

"Gelmeden önce bana hocaların öğrenci üzerinde baskı kurmaya çalıştıkları, kendilerini kanıtlamaya çalışıkları anlatılmıştı. Daha resmi ilişkiler, daha acımasız bir ortam. Öğrenciye değer vereceklerini sanmıyordum. Bir hoca daha samimi, iletişim kuruyor, yol gösteriyor; diğerleri iletişime girmiyor. Gelmeden önce de soğuk ve resmi bir ortam bekliyordum, öğrenciye değer vermezler, diye düşünüyordum. Gelince de böyle bir ortam buldum." (F1b)

"Özellikle kitaplarda ve filmlerde gördüğüm kadarıyla [öğretim elemanlarını] karakterleri oturmuş, öğrencilerinin karakterlerine saygı duyan insanlar olarak düşünüyordum. Kişisel gelişim açısından öğrenciye katkı sağlar, sosyalleşmesini sağlar, her yönden geliştirir. Bazı hocalar öğrenciye değer verirken birçoğu vermiyor. Öğrenciyle iletişim kurmuyorlar. (M4b)

Ayrıca öğrencilerin bir kısmı $(f=7)$ öğretim elemanlarının kendilerine birçok konuda rehberlik edeceği, yol göstereceği, hayata hazırlayacakları beklentisiyle üniversiteye başladıklarını dile getirmişlerdir. Çalışma sonuçları bu noktada beklentileri olmayan bazı öğrencilerin bile bu noktada yardım aldıklarını göstermekle birlikte $(f=9)$ bazı öğrencilerin bu konuda istedikleri yardımı alamadıklarını ortaya koymuştur $(f=8)$.

"Gelmeden önce kendimi hayata eksik hissediyordum. Üniversite hayata hazırlar, diye bekliyordum. Ama o konuda istediğimi bulamadım. [Öğretim elemanları] Pek yardımcı olmadılar. Rehberlik etmiyorlar. Beklediğim gibi değil. Daha sosyal bir ortam, daha sıcak, beni geliştirebilecek, ama onu göremedik." (F4a)

"Bazıları çok iyi rehberlik ediyor. Bir arkadaşın babası ölmüştü mesela. Ailesi köydeydi. Bir hocaya söyledim. Burs buldu. Destek sağladı. Arkadaşım okulu bırakmayı düşünüyordu. Eğer hoca yardım etmeseydi [arkadaşım] okulu bırakırdı." (M1a)

Öğretim elemanlarının eleştiriye açık olmaları konusunda üniversite öğrencilerinin üniversiteye başlamadan önceki ve başladıktan sonraki düşüncelerinin birbirinden farklı olduğu dikkati çekmektedir. Öğrenciler büyük çoğunlukla $(f=13)$ üniversiteye başlamadan önce öğretim elemanlarının eleştirilere açık olmasını beklerken, başladıktan sonra büyük çoğunluğunun $(f=13)$ bu konuda fikir değiştirerek öğretim elemanlarının eleştirilere kapalı olduklarını ifade ettikleri görülmüştür:

"Üniversite hocası gelişime, eleştiriye açık olur diye düşünüyordum. Ama öyle değiller." (F4a)

"Öğrencilerin konuşamayacağı kadar ciddi, havalı duruşları var. Söylediklerinden dolayı asla eleştiri kabul etmiyorlar. Onlarla ilgili eleştiri yapmamızı istedikleri bir anketi asla doldurmam. [Kendilerini] Pop star gibi ulaşılamaz görüyorlar." (F4b)

"Yükselmek için gelişime, eleştiriye açık olacaklarını düşünüyordum. Eleştiriye bazı hocalar açık, çoğu değil" (F1a) 
"Sonuçta hocalar akademik olarak yetişmiş insanlar. Bizim fikirlerimizle kendilerini yenileyeceklerini, eleştiriye açık olacaklarını bekliyordum. Bir kısım hocaların eleştiriye kapalı olduğunu düşünüyorum. Aksini iddia ettiğimizde bağıran hocalar var." (SB4b)

"Mesela kendi görüşüne karşıt iseniz tavırları değişiyor. Yeni fikirlere, gelişime kapalılar. Kendi görüşünün en doğru olduğunu düşünüyor." (F1b)

\section{Toplum ilişkileri}

Öğretim elemanlarının toplumla ilişkileri konusunda üniversite öğrencilerinin görüşleri farklııklar göstermektedir. Öğrencilerin bir kısmı $(f=10)$ öğretim elemanlarının toplumla resmi ilişkileri olacağı düşüncesiyle üniversiteye başlarken bir kısmı da $(\mathrm{f}=9)$ öğretim elemanlarının toplumla samimi ilişkiler içinde olacakları beklentisiyle üniversiteye başlamıştır. Ancak üniversiteye başladıktan sonra her iki gruptan fikrini değiştirmeyen öğrenciler olmakla birlikte fikri tamamen değişen öğrencilerin de olduğu görülmüştür. Bu değişim sonucunda öğrencilerin bir kısmı $(f=9)$ öğretim elemanlarını toplumla ilişkilerinde samimi bulmakta, bazıları ise $(f=8)$ öğretim elemanlarının toplumla ilişkilerini zayıf ya da resmi bulmaktadır.

"Çevreyle ilişkileri daha resmi olur. Kendilerini yüksek görürler, pek iç içe olmazlar diye düşünüyordum. Geldikten sonra samimi olduklarını gördüm." (SB1a)

"Ben akademisyenlerin halkla iç içe olması gerektiğini düşünürüm ama gerçekte öyle olmadığını gördüm. Çoğu odasından çıkmıyor. Toplumla iletişimi kopuk." (M4a)

"[Üniversiteye başlamadan önce] Öğretim elemanlarının havalı olmaması gerektiğini düşünüyordum. [Üniversiteye başladıktan sonra] Havalı olmadıklarını gördüm, kendini beğenmiş değiller. Bir eğitim hocasını otobüste görsem, sokakta yanından geçsem onun hiç öğretim elemanı olduğunu düşünmem." (M4b)

"Hocaların topluma örnek olacaklarını, yön vereceklerini düşünüyordum. Toplumla ilişkileri daha kopuk görünüyor, yeterli seviyede değil bence. Toplumda yol gösterici olmalı, fikir sunmalı, geri planda kalmamalılar." (F4a)

"Sonuçta kendini yetiştirmiş kişiler [öğretim üyeleri]. [Üniversiteye gelmeden önce] topluma örnek olacaklarını, fikirleriyle kitleleri etkileyeceklerini, toplumla işbirliği yapacaklarını, toplumsal olaylara duyarlı olacaklarını düşünüyordum. Üniversiteye başladıktan sonra birçok hocanın böyle olduğunu gördüm." (SB4b)

Öğrencilerin bir kısmı $(f=6)$ öğretim elemanlarının toplumdaki liderlerle ve kurumlarla işbirliği içinde olacaklarını, gerektiğinde derslerde bunlardan faydalanacaklarını düşünürken, bazıları üniversite ortamında böyle bir işbirliği olmadığını bazıları ise olduğunu ifade etmişlerdir.

"[Üniversiteye başlamadan önce] Çevrede bulunan kurum ve kuruluşların eğitim amaçlı kullanılacağını, gönüllü hizmetlerin yapılacağını düşünürdüm. Toplumun liderleriyle eğitimin liderlerinin işbirliği içinde olacağını, bunların derse yansıyacağını düşünürdüm. Hocaları çevre ve toplum ilişkileri açısından düşündüğüm gibi buldum. Çevre sorunları konusunda hassaslar. Çevredeki kurumlar eğitim amaçlı kullanılıyor hatta böyle bir ders bile var. Bu derste topluma hizmet konusunda eğitiliyoruz." (S1a) 
"[Öğretim elemanlarının] Çevreyle iyi ilişkiler içinde olacağını düşünüyordum. Çevreyle işbirliği yapar. Genelinin çevreyle iyi ilişkiler içinde olduğunu düşünüyorum. Çevre sorunlarına duyarlılar. Ama çevre olanaklarından derslerde faydalanılmıyor." (SB4a)

"Hocaların toplumdaki her şeyle, çevreyle ilgili fikirler ileri süren, duyarlı insanlar olduğunu düşünüyordum. Çevreye örnek, duyarlı, daha sosyal. Her konuda takip edilebilecek, örnek alınabilecek, insanlar diye düşünüyordum. Liderlerle, kurumlarla işbirliği olur. Geldikten sonra tam tersini buldum.[İlişkileri] O kadar kopuk. İşbirliği yok. (S4b)

"Akademisyenlerin halkla iç içe olması gerektiğini düşünüyorum ama gerçekte öyle olmadığını gördüm. Toplumla iletişimi kopuk. Kendi öğrencileriyle bile kopuk. Liderlerle, kurumlarla işbirliği yok." (M4a)

\section{Öğretim Elemanlarının "Mesleki Özellikleri" ile İlgili Üniversite Öğrencilerinin Düşünceleri}

Üniversite öğrencilerinin öğretim elemanlarının mesleki özellikleriyle ilgili düşünceleri analiz edildiğinde şu sonuçlara varılmıştır:

Tablo 2. Öğretim elemanlarının "mesleki özellikleri" ile ilgili öğrenci düşünceleri

\begin{tabular}{|c|c|c|c|c|c|c|c|c|c|}
\hline & & & & দ̆ & $\begin{array}{l}4 \\
\bar{E} \\
\dot{5}\end{array}$ & $\begin{array}{l}\Xi \\
E \\
\frac{E}{0} \\
\stackrel{0}{0}\end{array}$ & & $\begin{array}{l}\bar{E} \\
\overline{5}\end{array}$ & $\begin{array}{l}\Xi \\
E \\
\frac{E}{0} \\
\stackrel{0}{0}\end{array}$ \\
\hline & & & & \multicolumn{3}{|c|}{$\begin{array}{l}\text { Üniversiteye } \\
\text { başlamadan } \\
\text { önce }\end{array}$} & \multicolumn{3}{|c|}{$\begin{array}{l}\text { Üniversiteye } \\
\text { başladıktan } \\
\text { sonra }\end{array}$} \\
\hline \multirow{4}{*}{$\begin{array}{c}\text { Bilgi } \\
\text { düzeyi }\end{array}$} & \multirow{2}{*}{$\begin{array}{c}\text { Alan } \\
\text { bilgisi }\end{array}$} & \multicolumn{2}{|c|}{ Alanında uzman } & 9 & 10 & 19 & 8 & 4 & 12 \\
\hline & & \multicolumn{2}{|c|}{ Uzman değil } & & & & 2 & 6 & 8 \\
\hline & \multirow{2}{*}{$\begin{array}{l}\text { Genel } \\
\text { kültür } \\
\text { bilgisi }\end{array}$} & \multicolumn{2}{|c|}{ Yüksek/Yeterli } & 8 & 7 & 15 & 4 & 1 & 5 \\
\hline & & \multicolumn{2}{|c|}{ Yetersiz } & 1 & 2 & 3 & 6 & 8 & 14 \\
\hline \multirow{9}{*}{$\begin{array}{c}\text { Öğret } \\
\text { me- } \\
\text { öğren }\end{array}$} & \multirow{9}{*}{$\begin{array}{l}\text { Yöntem } \\
\text { ve } \\
\text { teknikler }\end{array}$} & \multirow[t]{2}{*}{$\begin{array}{l}\text { Yöntem } \\
\text { seçimi }\end{array}$} & $\begin{array}{c}\text { Geleneksel } \\
\text { yöntem }\end{array}$ & 5 & 2 & 7 & 9 & 8 & 17 \\
\hline & & & $\begin{array}{l}\text { Öğrenci } \\
\text { merkezli } \\
\text { yöntem }\end{array}$ & 3 & 8 & 11 & 1 & 2 & 3 \\
\hline & & \multirow{2}{*}{$\begin{array}{c}\text { Öğrencinin } \\
\text { öğrenmesi } \\
\text { için çaba } \\
\text { harcama }\end{array}$} & Evet & 1 & 3 & 4 & 4 & 1 & 5 \\
\hline & & & Hayır & 5 & 2 & 7 & 6 & 9 & 15 \\
\hline & & \multirow{2}{*}{$\begin{array}{c}\text { Dersi } \\
\text { materyalle } \\
\text { destekleme }\end{array}$} & Evet & 3 & 3 & 6 & 3 & & 3 \\
\hline & & & Hayır & 2 & 3 & 5 & 7 & 6 & 13 \\
\hline & & \multirow{2}{*}{$\begin{array}{l}\text { Ders dışı } \\
\text { etkinlikler } \\
\text { düzenleme }\end{array}$} & Evet & 5 & 5 & 10 & & & \\
\hline & & & Hayır & & 1 & 1 & 5 & 5 & 10 \\
\hline & & Daha fazla & Var & 4 & 6 & 10 & 1 & 2 & 3 \\
\hline
\end{tabular}



Karşılanma Düzeyine İlişkin Görüşleri

\begin{tabular}{|c|c|c|c|c|c|c|c|c|c|}
\hline \multirow[t]{9}{*}{$\begin{array}{c}\text { me } \\
\text { süreci }\end{array}$} & & \multirow{3}{*}{$\begin{array}{c}\text { uygulamalı } \\
\text { dersler }\end{array}$} & \multicolumn{4}{|l|}{ Yok } & \multirow{2}{*}{\multicolumn{2}{|c|}{45}} & \multirow{2}{*}{$\begin{array}{l}9 \\
2\end{array}$} \\
\hline & & & Evet & 2 & 6 & 8 & & & \\
\hline & & & Hayır & & & & 8 & 10 & 18 \\
\hline & \multirow{4}{*}{$\begin{array}{c}\text { Ölçme ve } \\
\text { değerlen } \\
\text { dirme }\end{array}$} & $\begin{array}{l}\text { Öğrenmele } \\
\text { ri ölçme }\end{array}$ & $\begin{array}{l}\text { Geleneksel } \\
\text { yöntemler }\end{array}$ & 2 & 4 & 6 & 7 & 7 & 14 \\
\hline & & yöntemi & $\begin{array}{c}\text { Alternatif } \\
\text { yöntemler }\end{array}$ & 5 & 5 & 10 & 2 & 3 & 5 \\
\hline & & \multicolumn{2}{|c|}{ Geribildirim yok } & & 1 & 1 & 5 & 8 & 13 \\
\hline & & \multicolumn{2}{|c|}{ Objektif değil } & & & & 2 & 1 & 3 \\
\hline & \multirow{2}{*}{$\begin{array}{c}\text { Sınıf } \\
\text { yönetimi }\end{array}$} & \multicolumn{2}{|c|}{ Katı kurallar } & 1 & 3 & 4 & 4 & 3 & 7 \\
\hline & & \multicolumn{2}{|c|}{ Esnek kurallar } & 5 & 2 & 7 & 1 & 2 & 3 \\
\hline
\end{tabular}

\section{Bilgi düzeyi}

Öğrenciler büyük çoğunlukla öğretim elemanlarının alan bilgisi ve genel kültür boyutlarında üst düzey bilgiye sahip olacakları beklentisiyle üniversiteye geldiklerini ve özellikle alan bilgisi boyutunda öğretim elemanlarının bu beklentilerini karşıladıklarını ifade etmişlerdir $(f=12)$. Ancak öğrencilerin büyük bir kısmı $(f=14)$ beklentilerinin aksine öğretim elemanlarının genel kültür düzeyini bekledikleri gibi bulmadıklarını dile getirmişlerdir.

"[Öğretim elemanı] Alanının her şekilde hakimi ve bunu sonuna kadar öğrencisine aktardığını düşünürdüm. Geldikten sonra da hocaların gerçekten alanlarında uzmanlaştıklarını gördüm." (S4a)

"[Öğretim elemanlarının] Genel kültürü seviyesini üst düzey bekliyordum. Beklediğim gibi bulmadım. Bazı hocalar beklentimin çok altında." (SB4b)

"Hayal kırıklığı içindeyim. Hocaların tam donanımlı olacaklarını, kafamızdaki tüm soru işaretlerini götüreceklerini düşünüyordum. Bazı hocaların yetersiz olduğunu gördüm." (F4a)

"Her şeyi bilen, uzman [kişiler] olduklarını düşünüyordum. Çok okur, araştırır, diye düşünüyordum. Bazı hocaların ders anlatışından belli ne kadar bilgili olduğu. Dersten gördüğüm kadarıyla bazıları soru sormamıza izin vermiyor, yetersiz kalıyor." (S1b)

"Alan bilgisi açısından gayet iyi hepsi. Genel kültür açısından yetersiz olanlar var. Okumuş, örnek insan ama tamamen iyi değil. Üniversite insana her şeyi kazandırmaz ki!" (M1b)

\section{Öğretme-öğrenme süreci}

Yöntem ve teknikler. Öğrenci merkezli öğretim stratejilerinin ön plana çıktığı günümüzde, üniversitede özellikle topluma öğretmen yetiştiren eğitim fakültelerinde, öğrenciler derslerin geleneksel yöntemlerden farklı olacağı, öğrenci merkezli yöntemlerle işleneceği beklentisiyle üniversiteye başlamıştır ancak 
öğrencilerin neredeyse tamamına yakını $(f=17)$ derslerin geleneksel yöntemlerle işlendiğini belirtmişlerdir.

"[Üniversiteye başlamadan önce] Kesinlikle düz anlatımın olduğu bir ders düşünmemiştim. Üniversite hocası anlatıyorsa çok farklı yöntemler olur, diye düşünmüştüm. Liseden farklı çok da bir şey görmedim. Çoğu derslerde düz anlatım yapıldı. Eğitim fakültesinde olması gereken uygulamaların çoğu zaman olmadığını gördüm." (F4b)

"Öğrenmemize çaba harcamıyorlar. 20 yıllık bir defteri alıp aynen yazıp giden hocalar da oldu. O defterden yazmaksa öğretmenlik onu ben de yazabilirdim. Ben buraya niye geldim? Sınav zamanı gider o hocanın notlarını alır, çalışır giderdim. Gelmeden önce daha öğrenci merkezli yöntemler beklerken geldikten sonra daha geleneksel yöntemler olduğunu gördüm." (M4b)

"Geleneksel yöntemler ağırlıkta. Bir ders dışında hep hoca anlatıyor, biz dinliyoruz. Çok az hoca bizi derse katıyor." (S1b)

"Birkaçı hariç çoğu hoca öğrenci merkezli yöntemler kullanmıyor, sadece dersini anlatıp gidiyor. Geleneksel yöntemler ağırlıkta. Öğrencinin öğrenmesi için çaba harcanmıyor, anladıysa anladı, anlamadıysa yapacak bir şey yok." (SB4b)

"Geleneksel yöntemler ağırlıkta. Bir ders dışında hep hoca anlatıyor, biz dinliyoruz. Çok az hoca bizi derse katıyor." (SB1b)

Derslerin işlenişiyle ilgili olarak, öğrencilerin çoğu $(f=15)$ öğretim elemanlarının öğrencinin öğrenmesi için çaba harcamadıklarını, derslerin materyalle desteklenmediğini $(f=13)$ ifade etmişlerdir. Bunlara ek olarak üniversite öğrencilerinin tamamına yakınının ( $f=18)$ öğretim elemanlarının bildiklerini öğrenciye aktaramadıkları görüşünde birleşmişlerdir.

"[Öğretim elemanı] Öğrencinin öğrenmesi için çaba harcamıyor, anladıysa anladı, anlamadıysa yapacak bir şey yok. Bazı hocalar derse giriyor, kendi kendine anlatıyor, ders işliyor; sanki arada bir duvar var, bizi görmüyor. Çok şaşırıyorum." S1b F1a

"[Derslerde] Materyal kullanılmıyor, sadece laboratuvar dersinde kullanıyoruz."

"Dersten gördüğüm kadarıyla [öğretim elemanları] gerçekten bilgili ama bize aktarmakta yetersiz kalıyor." (S1b)

"Bana üniversite denilince sürekli araştırma, daha bilimsel bir ortam aklıma geliyordu. Özgür düşünce. Öğrenci derse katılır, materyaller olur, şeklindeydi. Ders dışı etkinlikler olmasını isterdim. Dersler genellikle düz anlatımla anlatılıyor. Materyal göremedik. Kalabalık olduğumuz için çok anlamıyoruz anlatılanları. Hocaların bildiklerini aktarabildiğini sanmıyorum. Verimsiz oluyor. (SB1a)

Öğrencilerin üniversite deyince derslerle birlikte ders dışı etkinlikler de bekledikleri görülmektedir. Nitekim öğrencilerin birçoğu $(f=10)$ öğretim elemanlarından ders dışı etkinlikler de beklerken, aynı oranda öğrenci $(f=10)$ bunun gerçekleşmediğini dile getirmiştir. 
"Özellikle üniversite öğrencisi moda mod sınıfa gidecek, dersini işleyecek olmamalı, ders dışı etkinlikler, sosyal etkinlikler de olmalı." (M4a)

"Ders dışı etkinliklerin derslerden daha yoğun olacağını, hatta her hafta gezi, tiyatro, sinema, konferans, seminer, panel olacağını düşünüyordum. . Ders dışı etkinlikler yok denecek kadar az. Hocaların bu konuda yol gösterdikleri yok." (S1a)

Görüşmeler sırasında öğrenciler üniversitede verilen mesleki eğitimin hayata hazırlaması, pratiğe yönelik ve uygulamalı olması konusundaki beklentilerini dile getirmişlerdir ancak öğrenciler beklediklerinin aksine derslerde yeterince uygulamaya yer verilmediğini belirtmişlerdir. (F4a)

"Dersler daha uygulamalı olur diye beklerken daha teorik oldu. Verim alamadık."

"Uygulama sıfır. Derslerde öğrendiklerimizin çok işimize yarayacağını düşünmüyorum. Konuları derslerde işleyip geçiyoruz. Mezun olduğumda nasıl bir insan isem öyle öğretmen olacağım." (M1a)

"Üniversitelerin ben uygulama yeri olması gerektiğini düşünüyorum. Senenin bir haftasında oturup sınav yapmak bana çok doğru gelmiyor. Uygulamaya okullara gidiyoruz, çok güzel. İstekli olalım, motive olalım, gerçek anlamda bir şeyler araştıralım, öğrenelim, hocalarla tartışalım. Dersler uygulamalı olsun." (S4b)

Ölçme ve değerlendirme. Öğrenciler üniversitede çok yönlü ölçme ve değerlendirme sisteminin uygulanmasını, sadece sınavla değerlendirilmek istemediklerini belirtmişler ancak birçok öğrenci $(f=14)$ birçok derste alternatif ölçme ve değerlendirmenin yapılmadığı, klasik sınavlarla öğrenmelerinin ölçüldüğünü ifade etmişlerdir.

"[Üniversitede] Sürece yönelik not verilir, diye bekliyordum ama öyle değil. Sadece sınavla değerlendiriliyoruz. Sınıfımızda çok okuyan, genel kültürü iyi ama alttan çok dersi olan arkadaşlar var. Çok yönlü değerlendirme sistemi yok. Sadece belli alanda belli bilgileri ölçüyorlar." (M4a)

"Üçüncü sınıfta ölçme ve değerlendirme dersinde portfolyo hazırladık. Üç ay ödev hazırladım. Portfolyoyla değerlendirildik, hazırlamak çok zordu ama nasıl yapıldığını öğrendik. Sürece yönelik değerlendirme açısından olması gereken portfolyo, ama çok kullanılmıyor." (M4b)

"Dersleri anlatmak konusunda gayret gösterseler de anlayıp anlamadığımız konusunda sadece soru soruyorlar. Her derste yazılı sınav yapilıyor. Beden dersinde bile yazılı oluyoruz. Yani sözel ve uygulamalı ders ayrımı yok teknik ve yöntemler hep aynı." (S1a)

"Sürece yönelik, her şeye not verilir diye bekliyordum ama öyle değil. Sadece sınavla değerlendiriliyoruz. Çok ölçme değerlendirme objektif değil bence, hocanın muhatap olduğu kişiler daha iyi not alıyor." (M1b)

Öğrencilerin büyük kısmı $(f=13)$ sınavlardan sonra başarı durumlarıyla ilgili geribildirim olmadığını, hangi notu neden aldıklarını ya da herhangi bir dersten neden kaldıklarıyla ilgili çoğu zaman geribildirim olmadığını dile getirmişlerdir. Az 
sayıda öğrenci ( $f=3$ ) öğretim elemanlarının sınav sonuçlarını değerlendirirken objektif olmadıklarını düşündüklerini belirtmiştir.

"Bazen dersten geçerim diye düşünürken neden kaldığım hakkında bir bilgim olmadı. Geri bildirim olmuyor." (F4b)

"[Öğretim elemanları] Ölçme değerlendirme konusunda objektif değil bence, hocanın yakın olduğu kişiler daha iyi not alıyor." (M1b)

Sınıf yönetimi. Üniversiteye gelmeden önce sınıf yönetimi konusunda öğrencilerin bir kısmı $(f=4)$ katı kurallar beklerken, bir kısmı ise $(f=7)$ esnek kurallar uygulanacağını beklediklerini ifade etmişlerdir. Ancak başladıktan sonra tam tersi şekilde az sayıda öğrenci $(f=3)$ derslerde esnek kurallar bulmuş, daha fazla öğrenci $(f=7)$ ise derslerde katı kuralların uygulandığını ifade etmişlerdir.

"Sınıf yönetimi açısından daha esnek hayal etmiştim. Ama yoklamaya aşırı derecede önem veriliyor. Hatta yoklamadan sonra sınıf tekrar sayllıyor. Yoklamadan sonra gelen öğrenci ya derse alınmıyor ya da sınıfta duruyor fakat yok yazılıyor." (S1a)

"Öğretmenin sınıf kontrolü için çaba harcamayacağını, herkesin istediğini yapacağını hatta derse istedikleri gibi girip çıkacaklarını düşünüyordum. Yoklamaya aşırı derecede önem veriliyor." (S1a)

"Sınıf yönetimi açısından daha esnek bir ortam hayal etmiştim. Ama devam konusunda çok hassas hocalar var." (F4a)

\section{Tartışma ve Sonuç}

Üniversitelerin temel amacı, üniversitelerde öğrenim gören öğrencileri çağın gereklerine uygun bilgi, beceri, tutum ve değerlerle donatarak yetiştirmektir. Üniversite öğretim elemanlarının gerek kişisel gerekse mesleki özellikleri üniversite öğrencilerine verilen eğitimin kalitesi açısından oldukça büyük önem arzetmektedir. Bu bakımdan öncelikle öğretim elemanlarımız üstün niteliklere sahip olmalıdır ki onların yetiştirdiği öğretmen adaylarımız arzu edilen niteliklere sahip olsun ve gelecekte onların yetiştireceği kuşaklar da insani değerlerin kaybolmaya yüz tuttuğu dünyamızda iyi özelliklere sahip olarak yetişebilsin. Bu doğrultuda bu çalışmanın amacı üniversite öğrencilerinin üniversiteye başlamadan önce öğretim elemanlarından beklentilerini ve üniversiteye başladıktan sonra öğretim elemanlarının öğrencilerin bu beklentilerini karşılama düzeyini belirlemektir. Collins (2002) öğrencilerin öğretim elemanlarını değerlendirmesi sisteminin güçlü ve zayıf yanları olduğunu ancak, yeterli "ön bilgilendirme" ve "yönlendirme" ile sistemin üniversite, öğretim elemanları ve öğrenciler için daha "yapıcı" ve "etkin" hale gelebileceğini söylemektedir. Ancak öğrencilerden gelen bu geribildirimler sayesinde öğretim elemanlarımız yeterli ve yetersiz oldukları yönlerini görme fırsatını yakalayacaklardır.

Araştırma sonucunda üniversite öğrencilerinin üniversiteye başlamadan önce bekledikleri öğretim elemanı özellikleriyle üniversiteye başladıktan sonra karşılaştığı öğretim elemanı özelliklerinin farklılaştığı ortaya çıkmıştır. Öğrenciler üniversitedeki öğretim elemanlarını kişilik özellikleri açısından daha soğuk ve resmi beklerken üniversiteye başladıktan sonra daha samimi ve içten bulmuşlardır. Üniversiteyi kazanarak farklı bir eğitim kurumuna ilk defa başlayan tecrübesiz bir öğrencinin 
soğuk ve resmi bir ortam beklentisiyle tanımadığı bir kuruma gelmesi normal karşılanabilir. Öğrencilerin öğretim elemanlarını soğuk ve resmi insanlar sanmaları toplumda öğretim üyeleriyle ilgili var olan yanlış inançlardan da kaynaklanıyor olabilir. Ancak öğrenciler, sanılanın aksine, büyük oranda öğretim elemanlarını samimi ve içten insanlar olarak bulmuşlardır. Öğrencilerin öğretim elemanlarıyla rahat iletişime girebilmesi verilen eğitimin amaçlarına ulaşabilmesi için şarttır. Bu üniversite adına da olumlu bir durumdur. Böyle düşünen öğrencilerin varlığı toplumdaki öğretim elemanlarıyla ilgili olumsuz önyargıların da silinmesini sağlayacaktır. Kumral (2009) çalışmasında, olumlu olan öğretim elemanı davranışları arasında öğrenci ile iyi bir iletişim ve paylaşma olduğunu bildirmiştir. Wang ve diğ. (2007), üniversite öğrencileri tarafından görülen etkili öğretmen özellikleri arasında öğrencilerine ilgi gösterme; zayıf öğretmen özellikleri arasında ise öğrencilerle iletişimsizlik olduğunu belirtmişlerdir. Ergün ve diğ. (1999) de ideal öğretim elemanı nitelikleri arasında samimi olmayı saymaktadır.

Araştırma sonucunda üniversite öğrencilerinin çoğunluğu üniversiteye başlamadan önce derslerde öğrenci merkezli yöntemlerin kullanılmasını beklerken, üniversitede derslerde geleneksel yöntemlerin ağırlıklı olarak kullanıldığını belirtmişlerdir. Yapılandırmacı yaklaşıma göre hazırlanan yeni eğitim programını okullarda uygulamaları beklenen öğretmen adaylarının üniversitede geleneksel yöntemlerle eğitim görmesi kaygı verici bir durumdur. Öncelikle öğretim elemanlarımızın derslerde yapılandırmacı yaklaşımı ve öğrenci merkezli yöntemleri uygulamaları gerekmektedir. Onlardan model alarak öğretmenliği öğrenen öğretmen adayları ancak bu yolla yapılandırmacılığa göre ders işlemeyi öğrenebilirler. Bu ilk kademeden üniversite eğitimine kadar eğitim sistemimiz açısından önemli bir ihtiyaçtır. Ayrıca öğrencilerin çoğunluğu öğretim elemanlarının bildiklerini öğrencilere aktaramadıklarını düşünmektedir. Buradan öğretim elemanlarımızın öğrencinin konuyu kavramasını önemsemedikleri ya da pedagojik alan bilgilerinde eksiklikler olduğu anlaşılmaktadır. Öncelikle öğretim elemanlarımız derslerinde öğrenci merkezli yöntemlerle ders işlemeli, konuyu farklı yöntem ve stratejilerle anlatarak öğrencilerin daha iyi kavramasını sağlayabilmelidir. Bu yolla geleceğin öğretmenlerine de model olabilmelidirler. İnsancıl ve öğrenci merkezli öğrenme yaklaşımlarının popüler olduğu bu zamanda üniversitelerde geleneksel yöntemlerle derslerin işlenmesi olumsuz hatta geleceğimiz adına üzücü bir durumdur. Bu yalnızca eğitim fakültelerinde öğretim elemanları için değil, üniversitelerde öğrenim veren diğer tüm fakültelerdeki öğretim elemanları için geçerli bir durumdur. Alanları ne olursa olsun tüm fakültelerin öğretim elemanları eğitim pedagojik alan bilgisine sahip olmalı ve üniversite eğitiminde bunu kullanmalıdır. Alanı eğitim olmasa bile eğitim veren herkes eğitimle ilgili yöntem ve yaklaşımları bilmek zorundadır.

Öğrencilerin üniversiteye bu beklentilerle gelmiş olmaları ve öğretim elemanlarında göremedikleri bu özellikler daha önce bu konuda yapılan çalışmalarla paralellik göstermektedir. Arslantaş (2011), öğrenci görüşlerine göre, öğretim elemanlarının yarısından çoğunun "öğretim strateji-yöntem ve tekniklerini kullanma", "iletişim" ve "ölçme-değerlendirme" becerileri açısından yeterli düzeyde olmadıkları bulmuştur. Tam ve diğerleri (2009), çalışmalarında favori öğretmenleri müfredat ve eğitimle ilgili bilgi sahibi, öğrencinin öğrenmesini sağlamak için ders kitabı ve alıştırmalar arasında bağlantılar kuran, öğrencilerle ilgilenirken daha öğrenci merkezli yaklaşımlar kullananlar olarak belirlenmiştir. Ayrıca öğrencilerin üniversiteye yüksek 
beklentilerle gelmeleri ancak beklentilerinin karşılanmaması diğer çalışmalarla da uyumlu olarak öğretim elemanlarını beklentilerinin altında bulmuş olmaları olarak yorumlanabilir (Akgöl, 1994; Beyhan, 1994; Köseoğlu, 1994). Benzer şekilde başka bir araştırmada, öğretmen yetiştiren kurumlarda öğretim elemanlarının etkili öğretmenlik özelliklerinin belirlendiği bir çalışmada öğrenciler, etkili öğretmen özelliklerinin büyük çoğunluğunun öğretim elemanlarının "bir kısmı" tarafından yapıldığı veya öğretim elemanlarının "bir kısmı"nın bu davranışlarda yeterli olduğunu belirtmişler; ancak, öğretim elemanları etkili öğretmenlik özelliklerini gösterme veya yapma konusunda büyük bir çoğunluğunun "genellikle" gösterdiklerini ya da bu davranışlarda "oldukça yeterli" olduklarını ifade etmişlerdir (Şen ve Erişen, 2002).

Araştırmada üniversite öğrencilerinin öğretim elemanlarından beklediği alanında uzman, genel kültür düzeyi yüksek, öğrenci merkezli yöntemler kullanma, öğrencinin öğrenmesi için çaba harcama, dersi materyalle ve ders dışı etkinliklerle destekleme, sınıf yönetiminde esnek kurallar, öğrencilere rehberlik etme, çevreye duyarlı ve örnek davranışlar sergileme gibi özellikler bu konuda diğer yapılan çalışmalarda istenilen öğretim elemanı özellikleriyle örtüşmektedir (Özdemir ve Üzel, 2010; Kumral, 2009; Wang ve diğerleri, 2007; Ergün ve diğ., 1999).

\section{Öneriler}

1. Öğretim elemanlarının soğuk ve resmi olduğu inancının aksine öğrencilerin öğretim elemanlarını samimi ve içten bulmaları oldukça pozitif bir durumdur. Toplumdaki öğretim elemanlarının soğuk ve resmi olduğu inancı üniversitelerin geleceği açısından değiştirilmesi gereken bir kanıdır.

2. Üniversite ortamında derslerde geleneksel yöntemler yerine öğrenci merkezli yöntemler tercih edilmelidir. Öğretim elemanları kendi bilgi ve becerilerini farklı yöntem ve tekniklerle öğrencilerin kavraması için çaba harcamalıdırlar.

3. Eğitim fakültesinde yapılan bu araştırma diğer fakültelerde de yapılarak genişletilebilir. Bu çalışmayla benzerlik ve farklılıklar açısından karşılaştırma imkanı sağlanabilir.

4. Üniversitelerdeki yalnız eğitim fakülteleri değil diğer tüm bölümlerdeki öğretim elemanlarının eğitim pedagoji bilgileri ve bunları derslerde ne kadar uyguladıkları araştırılabilir.

\section{Kaynaklar}

Akgöl, H. (1994). Eğitim Fakültelerindeki Öğretim Elemanları ve Öğrencilerin İdeal Bir Öğretim Elemanının Nitelikleri Hakkındaki Görüşleri ile Kendi Kurumlarındaki Öğretim Elemanlarının Bu Niteliklere Uygunluklarının Karşılaştırılması. Yayımlanmamış Doktora Tezi. Dokuz Eylül Üniversitesi, Sosyal Bilimler Enstitüsü, İzmir.

Akpınar, B., Turan, M. ve Tekataş, H. (2004). Öğretmen Adaylarının Gözüyle Sınıf Öğretmenlerinin Yeterlilikleri. XIII. Ulusal Eğitim Bilimleri Kurultayı, İnönü Üniversitesi, Eğitim Fakültesi, Malatya. 
Arslantaş, H. İ. (2011). Öğretim Elemanlarının Öğretim Stratejileri, Yöntem ve Teknikleri, İletişim ve Ölçme Değerlendirme Yeterliklerine Yönelik Öğrenci Görüşleri. Mustafa Kemal Üniversitesi Sosyal Bilimler Enstitüsü Dergisi, Cilt: 8, Sayı: 15, 487 - 506.

Beyhan, N. (1994). İlkokullara Sınıf Öğretmeni Yetiştiren Eğitim Yüksekokullarındaki Ögretim Elemanı ve Öğrencilerin İdeal bir Öğretim Elemanının Nitelikleri Hakkındaki Görüşleri ile Kendi Kurumlarındaki Öğretim Elemanlarının Bu Niteliklere Uygunluklarının Karşılaştırılması. Yayınlanmamış Doktora Tezi. Dokuz Eylül Üniversitesi, Sosyal Bilimler Enstitüsü, İzmir.

Collins, A.B. (2002). Üniversite Öğrencileri Öğretim Elemanlarının Başarısını Değerlendirebilir mi? İkilemler ve Problemler. Ankara Üniversitesi, Eğitim Bilimleri Fakültesi Dergisi, Cilt 35, Sayı 1-2, 81-91.

Ergün, M., Duman, T., Kıncal, R. Ve Arıbaş, S. (1999). İdeal Bir Öğretim Elemanının Özellikleri. Afyon Kocatepe Üniversitesi, Sosyal Bilimler Dergisi. Sayı 3, 1-11.

Gelen, İ., Özer, B. (2008). Öğretmenlik Mesleği Genel Yeterliliklerine Sahip Olma Düzeyleri Hakkında Öğretmen Adayları ve Öğretmenlerin Görüşlerinin Değerlendirilmesi. Mustafa Kemal Üniversitesi Sosyal Bilimler Enstitüsü Dergisi. Cilt: 5, Sayı: 9, 39-55.

Gregory, K. M. (2012). How Undergraduates Perceive Their Professors: A Corpus Analysis Of Rate My Professor. J. Educational Technology Systems. Vol. 40(2) 169-193.

Köseoğlu, K. (1994). İlköğretime Öğretmen Yetiştiren Kurumlarda Öğretim Elemanı Yeterliliklerinin Değerlendirilmesi. Yayımlanmamış Yüksek Lisans Tezi. Ankara Üniversitesi, Sosyal Bilimler Enstitüsü, Ankara.

Kumral, O. (2009). Öğretmen Adaylarının Öğretim Elemanlarının Davranışlarına Yönelik Algıları. Pamukkale Üniversitesi Eğitim Fakültesi Dergisi, sayı 25, 92102.

Milli Eğitim Bakanlığı, Öğretmen Yetiştirme ve Eğitimi Genel Müdürlüğü (2006). Öğretmenlik Mesleği Genel Yeterlilikleri. otmg.meb.gov.tr/belgeler/Yeterlikler.doc, 23. 04. 2012.

Numanoğlu, G. ve Bayır, Ş. (2009). Bilgisayar Öğretmen Adaylarının Öğretmenlik Mesleği Genel Yeterliklerine ilişkin Görüşleri. Ahi Evran Üniversitesi Kırşehir Eğitim Fakültesi Dergisi (KEFAD) Cilt 10, Sayı 1, 197-212.

Özdemir, E., Üzel, D. (2010). İlköğretim Matematik Öğretmen Adaylarının Öğretim Elemanı Özelliklerine Yönelik Görüşlerinin İncelenmesi. Mehmet Akif Ersoy Üniversitesi Eğitim Fakültesi Dergisi, Sayı 20, 122 - 152.

Saylan, N., Uyangör, N. (1998). Öğrenci Görüşlerine Göre Necatibey Eğitim Fakültesi Öğretim Elemanlarında Bulunan Öğretmenlik Niteliklerinin Belirlenmesi. Balıkesir Üniversitesi Sosyal Bilimler Enstitüsü Dergisi, Cilt: 1 Sayı: 2, 35-67.

Senemoğlu, N. (2011). Gelişim, Öğrenme ve Öğretim (21. Baskı). Ankara: PegemA.

Slate, J. R., LaPrairie, K., Schulte, D. P., Onwuegbuzie, A. J. (2009). A Mixed Analysis of College Students' Best And Poorest College Professors. Issues in Educational Research, 19(1),61-78.

Şen, H. Ş., Erişen, Y. (2002). Öğretmen Yetiştiren Kurumlarda Öğretim Elemanlarının Etkili Öğretmenlik Özellikleri. G.Ü. Gazi Eğitim Fakültesi Dergisi Cilt 22, Sayı 1, 99-116. 
Tam, K. Y., Heng, M. A., Jiang, G. H. (2009). What Undergraduate Students in China Say About Their Professors' Teaching. Teaching in Higher Education, Vol. 14, No. 2, 147-159.

Varış, F. (1994). Eğitim Bilimine Giriş. Ankara: Ankara Üniversitesi Yayınları.

Wang, J., Gibson, A. M., Slate, J. R. (2007). Effective Teachers as Viewed by Students at a 2 Year College: A Multistage Mixed Analysis. Issues in Educational Research, 17(2), 272- 295.

Yıldıım, A. ve Şimşek, H. (2011). Sosyal Bilimlerde Nitel Araştırma Yöntemleri. Ankara: Seçkin Yayınclık. 